\title{
Effect of Materials For Interim Restoration on Estimation of Working Length Using Electronic Apex Locator: in vitro Study
}

\author{
Efecto de Materiales Para Restauración Intermedia sobre la Estimación de la Longitud \\ de Trabajo Endodóntico Utilizando Localizador Electrónico de Foramen: Estudio in vitro
}

\author{
Ortega F.; Romero L.; Echeverri D. \& Aguilera F.
}

ORTEGA, F.; ROMERO L.; ECHEVERRI, D. \& AGUILERA, F. Effect of materials for interim restoration on estimation of working length using electronic apex locator: in vitro study. Int. J. Odontostomatol., 15(2):421-426, 2021.

\begin{abstract}
The aim of this in vitro study was to evaluate measurement accordance using an electronic apex locator for estimation of working length in endodontics when different restorative materials for interim crown restoration are utilized. For this study, 13 single-rooted premolars with endodontic occlusal access cavity were prepared. To establish the working length of each tooth, these were mounted in alginate and with the help of an electronic foramen locator and endodontic file K-file \# 15, the working length was established. This length was later compared to the estimated working lengths using different intermediate restoration materials. These materials were: Superior Chemfil, Ketac ${ }^{\mathrm{T} M}$ Molar Easymix and Filtek z350 resin. In the electronic measurements, an acceptable tolerance range of variation up to $\pm 0.5 \mathrm{~mm}$ was considered. Highest discrepancies were considered erroneous. For these measurements, central tendency and dispersion were analyzed. The Bland-Altman method was used, and the ANOVA test with a significance level of $p<0,05$ for statistic difference. Regarding measurements' acceptability and the type of interim restoration material utilized, 7 were acceptable, and 6 were unacceptable for ChemFil Superior, 12 were acceptable and 1 unacceptable for Ketac ${ }^{\mathrm{TM}}$ Molar Easymix, and 11 were acceptable and 2 were unacceptable for Filtek Z350 composite resin. The average difference between all electronic measurements was 0.29 $( \pm 0.44)$. Chemfill Superior showed the most prominent variation between measurements $0.58( \pm 0.45)$. When using an electronic apex locator, measurements showed statistically significant differences depending on the interim restoration material of choice $(p<0.05)$. In conclusion, the measurement accordance using electronic apex locator to estimation the working length is higher, however the electronic estimation of working length can be significatively affected by the material chosen for interim temporary restoration.
\end{abstract}

KEY WORDS: Interim restoration, electronic apex locator, working length.

\section{INTRODUCTION}

The removal of necrotic pulp tissue is fundamental for success within endodontic therapy (Gordon \& Chandler, 2004). In order to achieve this, Working Length (WL) must be determined, which is defined as the distance between a coronal reference point and the point where the root preparation and obturation ends (American Association of Endodontists, 2003). In consequence, WL should be measured as accurately as possible.

To target this accurate measurement, $\mathrm{WL}$ has been traditionally determined through the radiographic method (Aggarwal et al., 2017). Nevertheless, certain limitations pertain to such technology such as inherent image distortion in radiography, difficulty to carry out direct measurements, and its variability of interpretation by a given operator (Leonardo et al., 2008). In order to overcome the limitations associated with this method, the use of an Electronic Apex Locator (EAL), which has shown to be superior in terms of accuracy for determining WL (Kobayashi \& Suda, 1994; Fouad \& Reid, 2000), besides its advantages for being a fast and easy-to-use device, and diminishing the patient's exposure to ionising radiation throughout endodontic treatment (Gordon \& Chandler) has been introduced. This device works with electric impedance (Nekoofar

Dental School, Faculty of Medicine, Universidad Austral de Chile, Valdivia, Chile.

Received: 2019-07-17 Accepted: 2020-11-12 
et al., 2006), defined as the electric opposition to the flow of alternating current provided by a given material in a determined frequency (Pallás Areny, 2006).

Since teeth for which endodontic treatment has often been indicated have lost considerable coronal tooth structure (Alonso et al., 2009), the reconstruction of dental tissue using interim obturation materials, could allow adequate insulation, improved irrigation, and the possibility to locate a coronal reference point from which WL can be accurately determined. Each of these materials presents inherent physical properties, one of them being the opposition to electric current flow. This particular property could either facilitate or limit the current flow emitted from the electronic apex locator circuit towards the oral tissue, likely altering measurement (Al-bulushi et al., 2008). As previously mentioned, the objective of this study is to evaluate the accordance of the WL measurements provided by EAL with a variety of materials for coronal interim restoration.

\section{MATERIAL AND METHOD}

In our experimental in vitro study, freshly extracted human premolars were used, posterior to the acquisition of informed consent from patients, during the clinical cycle in the subject of Oral Surgery in the Dental School of the Universidad Austral de Chile (Austral University of Chile). This study was approved by the Ethics and Scientific Committee of the Health Department in the Region of Los Ríos in Valdivia, Chile.

Following dental extraction, all teeth were disinfected with Timol $0.1 \%$ to be then stored in an isotonic physiological solution (Sodium Chloride $0.9 \%$, Fresenius Kabi) in individual glass recipients and kept at $4^{\circ} \mathrm{C}$ in a container until their intervention. Each of the teeth was assigned a sample code, which was specified on the storage recipient. Subsequently, two periapical radiographs were taken of each tooth with a buccolingual and mesial-distal perspective aiming to observe the pulp chamber and the anatomy of the root canals.

Clinically healthy single-rooted premolars with a completely formed apex were included, and those presenting, aberrant root anatomy, internal or external resorption as well as calcified root canals, which were clinically and radiographically assessed, were excluded.
Subsequently, access openings for endodontic treatment were prepared upon the selected teeth, their occlusal surface was abraded to obtain a coronal reference for measurement and lastly disinfected with $5.25 \%$ sodium hypochlorite for 1 minute using a monojet $3 \mathrm{ml} 27 \mathrm{G}$ syringe (Kendall). All of the measurements in the study were performed with a mini Endoblock endodontic ruler (Dentsply Maillefer, Ballaigues, Switzerland) established in millimeters ( $\mathrm{mm})$.

Each tooth was submerged in alginate (Jetrate chromatic Dentsply) to the cementoenamel junction to estimation working length through the use of an electronic apex locator (ProPex II, Dentsply Maillefer, Ballaigues, Switzerland), with a number \#15 K-file (Dentsply Maillefer, Ballaigues, Switzerland). This working length was established until the electronic apex locator "Apex" and was considered as a gold standard for comparisons of theestimated lengths with the different interim restoration materials.

Once measurements were established through EAL on each tooth, a proximal surface was eliminated from the crown using a surgical length tapered diamond bur, thus transforming the occlusal cavity into an occlusal-proximal one (class II), prepared to the cementoenamel limit. This proximal cavity was restored with one of the coronal interim restoration materials, for later estimation of WL through EAL: Chemfil superior (Dentsply Maillefer, Ballaigues, Switzerland), Ketac $^{\mathrm{TM}}$ Molar Easymix (3M) and Filtek z350 (3M) resin. After the estimation of working length, proximal restoration was removed using the surgical length tapered diamond bur and an ultrasonic tip (E7D Nsk) to avoid alteration of the dimensions of the cavity. In electronic measurements, the acceptable tolerance range in length was a variation between of $\pm 0.5 \mathrm{~mm}$. Higher discrepancies were considered erroneous.

All of the measurements were performed by the same observer (F.O) qualified by a specialist in endodontics with clinical experience (D.E). In order to establish the degree of diagnostic certainty among measurements performed both intra and interobserver, the intraclass correlation coefficient (ICC) was calculated, established according to Landis \& Koch's classification (Landis \& Koch, 1977), which classifies the strength of reliability in: poor $(0.00)$, slight $(0.01$ $0.2)$, fair $(0.21-0.4)$, moderate $(0.41-0.6)$, substantial (0.61-0.8), and almost perfect (0.81-1).

The data were tabulated in a Google spreadsheet and later exported to .csv format for the 
public access statistics program Rv.3.5.1, where the correspondent data analysis was performed.

Measures of central and dispersion-tendency were calculated for the different measurements. Besides, the analysis of individual differences wasperformed, for each of the selected measurements with different interim restoration materials, using specific Bland-Altman method. Finally, in order to determine statistical significance in the difference between measurements, an ANOVA test with a statistical level of significance of $p<0.05$ was performed.

\section{RESULTS}

A total of 13 premolars met the criteria mentioned above and were included in the study. There were no statistically significant differences while performing measurements intra and interobserver and ICC was $>0.81$, which revealed an almost perfect reliability coefficient, as prescribed by Landis \& Koch.

Regarding measurements acceptability and the type of interim obturation material utilized, 7 were acceptable, and 6 were unacceptable for ChemFil Superior, 12 were acceptable and 1 unacceptable for Ketac $^{\mathrm{TM}}$ Molar Easymix, and 11 were acceptable and 2 were unacceptable for Filtek Z350 composite resin (Table I).

Table I. Tolerance according to each material.

\begin{tabular}{lll}
\hline & \multicolumn{2}{c}{ Tolerance $^{\text {a }}$} \\
\hline Interim material & Acceptable & Erroneous $^{-}$ \\
\hline ChemFil Superior & 7 & 6 \\
Ketac $^{\mathrm{TM}}$ Molar & 12 & 1 \\
Resin Filtek Z350 & 11 & 2 \\
\hline
\end{tabular}

a Values are given as $\mathrm{n}$ according to tolerance in electronic measurements for each group.
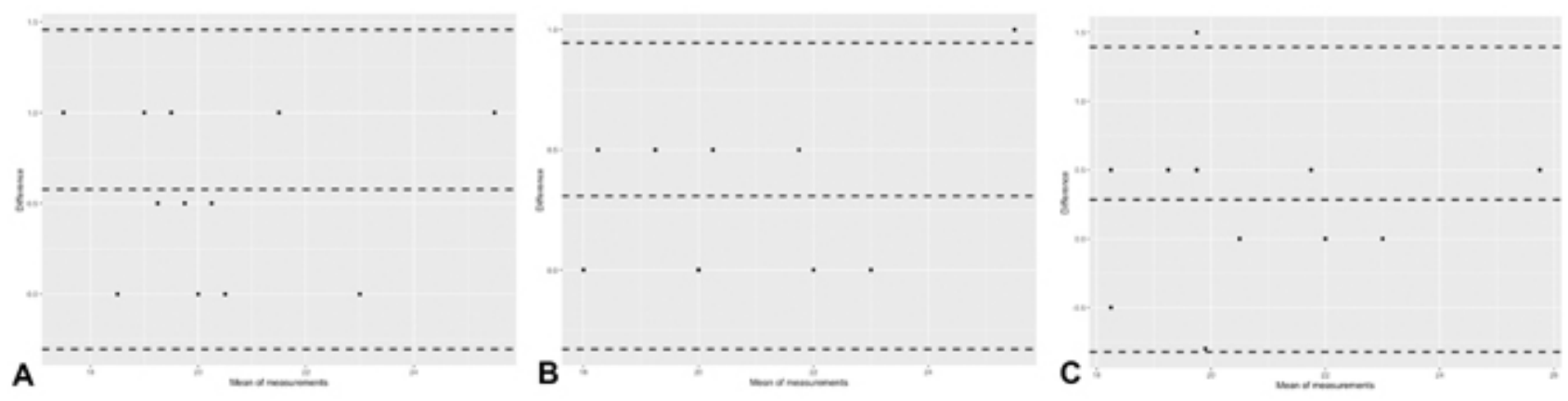

Fig. 1. Bland-Altman plot. Evaluation of the accordance between different measurements; (A) Proximal cavity restored with Chemfil Superior, (B) Proximal cavity repaired with Ketac ${ }^{\mathrm{TM}}$ Molar Easymix and (C) restored with Composite Resine Filtek $z 350$.
The average difference between all electronic measurements from the gold standard was 0.29 ( \pm $0.44)$. On the other side, the variation average between measurements for Chemfil Superior was $0.58( \pm 0.45)$, 0.31 ( \pm 0.33$)$ for Ketac ${ }^{\mathrm{TM}}$ Molar Easy Mix and 0.28 ( \pm 0.57 ) for Filtek Z350. ANOVA test revealed statistically significant differences among the absolute discrepancy in the measurements performed $(p<0.05)$. The differences between measurements (Mean \pm SD) are shown in Table II.

Table II Electronic Apex Locator measurement differences.

\begin{tabular}{lll}
\hline Interim material & $\begin{array}{l}\text { Difference between } \\
\text { measurements }(\mathrm{mm})\end{array}$ & $\mathrm{P}$ \\
\hline ChemFil Superior & $0.58(\mathrm{SD} \pm 0.45)$ & ${ }^{*}$ \\
Ketac $^{\mathrm{TM}}$ Molar & $0.31(\mathrm{SD} \pm 0.33)$ & $\mathrm{ns}$ \\
Resin Filtek Z350 & $0.28(\mathrm{SD} \pm 0.57)$ & $\mathrm{ns}$ \\
\hline
\end{tabular}

ANOVA test was used to compare the differences between measurements performed with an electronic apex locator.

Statistical significance was set at: $p<0.05\left(^{*}\right)$.

$\mathrm{SD}=$ standard deviation

ns $=$ not significant

Bland-Altman's analysis demonstrated that average values for the inferior and superior limits were higher for measurements within the Chemfil Superior group (Fig. 1).

\section{DISCUSSION}

The present study revealed high consistency among WL measurements performed on teeth presenting only occlusal access cavity, using EAL, in contrast with measurements performed later in the same teeth with a proximal interim restoration. 
During electronic working length estimation, dentine acts as an insulator between the file (electrode) and the oral tissue. Once the file comes out of the tooth through the apical foramen, it makes contact with periapical tissue and the electronic device detects minor resistance to the current flow, given that impedance (opposition to current flow) of the periodontal ligament, as well as impedance in the oral mucosa, has a constant value of $6.5 \mathrm{k} \Omega$ (Gordon \& Chandler).

On this basis, any structure loss in crown dentin (insulator) might allow an undesirable current flow between the electrode and the oral tissue before it reaches the apical foramen, causing eventually erroneous readings by the electronic device.

According to our results, working length measurements obtained in teeth with proximal class II cavities restored with Chemfil Superior, showed the highest inconsistency among all. Glass ionomer cements present particular electric characteristics that vary throughout the setting process, getting stable up to 5 days after mixing (Villat et al., 2010; Babu et al., 2012). Babu et al. studied the dielectric and thermal properties of these materials and found that under $80^{\circ} \mathrm{C}$ this material behaves as a conductor and polar substance. Their electric resistance increases throughout the setting time.

In their study, Tay \& Braden (1984) compared the electric properties of two glass ionomer cements (Ketac Cem and Chemfil Superior). They found that resistance and electrical permittivity varied during the early stages up to the final setting reaction. The electrical resistance pertains to the opposition to electrons flow in a given material as permittivity relates to the capacity of such material to store electric energy. In their study, typical behavior for ionomer glass cement was observed, being resistant to electron flow (insulator) once the total setting was achieved. During the early stages of the setting reaction, however, their properties varied from each other, with Ketac Cem showing significantly lower permittivity throughout the whole setting process, especially with a high liquid-powder ratio.

Another material tested in our study is composite resin. When teeth were restored by this means, they showed consistency in their electronic measurements. Marcinkowska et al. (2017) studied the electrical properties of different dental materials regarding temperature, as a means to estimate the material's deterioration. The order in which the assessed materials behaved as electric insulators was shown as follows: temporary prosthetic compounds, resinbased fissure sealants, composite resins and finally ionomer-modified resins, being the last ones the best electrical conductor.

It is worth mentioning that the use of EAL to determine WL, can be affected by several different factors, such as apical foramen size (EIAyouti et al., 2005), type and size of the utilized measuring file (Ebrahim et al., 2006), electroconductivity of the pulp (Ebrahim et al., 2007) and the type of solution used for irrigation (Ebrahim et al., 2007; Khattak et at., 2014; Janeczek et al., 2016). Studies like the one performed by Khattak et al. have determined the precision of EAL in the presence of different irrigating solutions such as saline solution, chlorhexidine and sodium hypochlorite, reporting that there were no differences among the real length measurements and the ones performed with EAL.

Up to the point of the present study, no information on the effects of electric conductivity of materials for coronal interim restoration on the precision of the electronic estimation of working length was found in the literature. Considering that teeth undergoing endodontic treatment often present considerable structure losses, it would be desirable to select a material that offers acceptable marginal sealing as well as enough resistance to the current flow to favor the accuracy in electronic measurements of the root canal.

A limitation frequently found in all in vitro studies is the extrapolation of the obtained data into the clinical environment. Several electro-conductive materials to replicate characteristics of the buccal mucosa and periodontal ligature have been utilized, among which alginate, gelatine, agar or phosphate-buffered saline have been proposed to serve as testing models, offering replicable results whenever EAL used (Czerw et al., 1994; Meares \& Steiman, 2002).

In a study by Czerw et al. all of these testing means were compared, concluding that the alginate model is more stable, given that its relative rigidity makes it unlikely to be introduced through the apical foramen, thus avoiding the possibility of premature readings. The relative effect of humidity and elapsed time from the moment of the test assembly to the moment of the measurement using the locator, was also studied, and despite the fact that the differences in readings were statistically insignificant, it is not recommended to exceed the lapse of 24 hours, to avoid the possible contraction of the material and the reduction of humidity. 
For this investigation, we utilize a Propex II EAL. It is suggested that further studies are carried out to evaluate whether other apex locators would also reduce accuracy as a consequence of differences in electrical properties of the materials used for interim coronal restoration during endodontic treatment.

In conclusion the measurement accordance using EAL to determine $\mathrm{WL}$ is higher, however the electronic estimation of working length can be significatively affected by the material chosen for interim temporary restoration. Clinicians should hold these results into consideration at the moment of choosing the material for crown reconstruction when performing endodontic treatment.

\section{ACKNOWLEDGMENTS}

Dental School, Faculty of Medicine, Universidad Austral de Chile, Valdivia, Chile. Ethics and Scientific Committee of the Health Department in the Region of Los Ríos in Valdivia, Chile.

ORTEGA, F.; ROMERO L.; ECHEVERRI, D. \& AGUILERA, F. Efecto de materiales para restauración intermedia sobre la estimación de la longitud de trabajo endodóntico utilizando localizador electrónico de foramen: estudio in vitro. Int. J. Odontostomatol., 15(2):421-426, 2021.

RESUMEN: El objetivo de este estudio in vitro, fue evaluar la concordancia de las estimaciones de longitud de trabajo mediante localizador electrónico de foramen, utilizando diferentes materiales de restauración intermedia coronaria. Para tales fines fueron preparados 13 premolares uniradiculares con cavidad de acceso oclusal endodóntico. Para establecer la a longitud de trabajo de cada diente, estos fueron montados en alginato y con la ayuda de un localizador electrónico de foramen y lima de endodoncia K-file \#15 fue establecida la longitud de trabajo. Esta longitud fue comparada posteriormente con las longitudes de trabajo estimadas utilizando diferentes materiales de restauración intermedia. Estos materiales fueron: Chemfil superior, Ketac ${ }^{\mathrm{TM}}$ Molar Easymix y resina Filtek z350. En las mediciones electrónicas, se consideró un rango de tolerancia aceptable de variación hasta $\pm 0,5 \mathrm{~mm}$. Las discrepancias mayores se consideraron erróneas. Se calcularon medidas de tendencia central y la dispersión. Se utilizó el método de BlandAltman y la prueba ANOVA con un nivel de significancia de $p$ $<0,05$. Con respecto a la aceptabilidad de las mediciones y el tipo de material de restauración intermedia, 7 fueron aceptables y 6 fueron inaceptables para ChemFil Superior, 12 fueron aceptables y 1 inaceptable para Ketac TM Molar Easymix, y 11 fueron aceptables y 2 fueron inaceptables para el compuesto Filtek Z350 resina. La diferencia promedio entre todas las mediciones electrónicas fue de 0,29 $( \pm 0,44)$. Chemfil Superior mostró la mayor variación entre mediciones $0,58( \pm 0,45)$. Las mediciones mostraron diferencias estadísticamente significativas dependiendo del material de restauración intermedio elegido $(\mathrm{p}<0,05)$. En conclusión, la concordancia en la estimación de la longitud de trabajo usando localizador electrónico de foramen es alta, sin embargo, puede verse afectada significativamente por el material de obturación intermedio.

PALABRAS CLAVE: Restauración intermedia, localizador electrónico, longitud de trabajo.

\section{REFERENCES}

Aggarwal, V.; Singla, M. \& Bhasin, S. S. Influence of instrument size and varying electrical resistance of root canal instruments on accuracy of three electronic root canal length measurement devices. Int. Endod. J., 50(5):506-11, 2017.

Al-bulushi, A.; Levinkind, M.; Flanagan, M.; Ng, Y. L. \& Gulabivala, $\mathrm{K}$. Effect of canal preparation and residual root filling material on root impedance. Int. Endod. J., 41(10):892-904, 2008.

Alonso, M. E.; Calabria, D. H.; Lorenzo, I. A.; Nelly, G. D. \& Vola, J. Manejo clínico de la caries profunda. Odontoestomatología, 11(13):59-67, 2009.

American Association of Endodontists. Glossary of Endodontic Terms. 7th ed. Chicago, American Association of Endodontists, 2003.

Babu, T.A.; Ramesh, K.V. \& Sastry, D.L. Studies on electrical and thermal properties of dental glass ionomer cement. J. Biomed. Sci. Eng., 05(11):634-638, 2012.

Czerw, R. J.; Fulkerson, M. S. \& Donnelly, J. C. An in vitro test of a simplified model to demonstrate the operation of electronic root canal measuring devices. J. Endod., (12):605-6, 1994.

Ebrahim, A. K.; Wadachi, R. \& Suda, H. An in vitro evaluation of the accuracy of dentaport ZX apex locator in enlarged root canals. Aust. Dent. J., 52(3):193-7, 2007.

Ebrahim, A. K.; Yoshioka, T.; Kobayashi, C. \& Suda, H. The effects of file size, sodium hypochlorite and blood on the accuracy of root ZX apex locator in enlarged root canals: an in vitro study. Aust. Dent. J., 51(2):153-7, 2006.

ElAyouti, A.; Kimionis, I.; Chu, A. L. \& Löst, C. Determining the apical terminus of root-end resected teeth using three modern apex locators: a comparative ex vivo study. Int. Endod. J., 38(11):82733, 2005.

Fouad, A. F. \& Reid, L. C. Effect of using electronic apex locators on selected endodontic treatment parameters. J. Endod., 26(6):3647, 2000 .

Gordon, M. P. J. \& Chandler, N. P. Electronic apex locators. Int. Endod. J., 37(7):425-37, 2004.

Janeczek, M.; Kosior, P.; Piesiak-Panczyszyn, D.; Dudek, K.; Chrószcz, A.; Czajczynska-Waszkiewicz, A.; Kowalczyk-Zajac, M.; Gabren-Syller, A.; Kirstein, K.; Skalec, A.; et al., The effect of file size and type and irrigation solutions on the accuracy of electronic apex locators: an in vitro study on canine teeth. Biomed. Res. Int., 2016:8594087, 2016.

Khattak, O.; Raidullah, E. \& Francis, M. L. A comparative assessment of the accuracy of electronic apex locator (Root ZX) in the presence of commonly used irrigating solutions. J. Clin. Exp. Dent., 6(1):41-6, 2014. 
ORTEGA, F.; ROMERO L.; ECHEVERRI, D. \& AGUILERA, F. Effect of materials for interim restoration on estimation of working length using electronic apex locator: in vitro study. Int. J. Odontostomatol., 15(2):421-426, 2021.

Kobayashi, C. \& Suda. H. New electronic canal measuring device based on the ratio method. J. Endod., 20(3):111-4, 1994.

Landis, J. \& Koch, G. The measurement of observer agreement for categorical data. Biometrics, 33(1):159-74, 1977.

Leonardo, M. R.; Silva, L. A.; Nelson-Filho, P.; Silva, R. A. \& Raffaini, M. S. Ex vivo evaluation of the accuracy of two electronic apex locators during root canal length determination in primary teeth. Int. Endod. J., 41(4):317-21, 2008.

Marcinkowska, A.; Gauza-Wlodarczyk, M.; Kubisz, L. \& Hedzelek, $W$. The electrical properties and glass transition of some dental materials after temperature exposure. J. Mater. Sci. Mater. Med., 28(12):186, 2017.

Meares, W. A. \& Steiman, H. R. The influence of sodium hypochlorite irrigation on the accuracy of the Root ZX electronic apex locator. J. Endod., 28(8):595-8, 2002.

Nekoofar, M. H.; Ghandi, M. M.; Hayes, S. J. \& Dummer, P. M. The fundamental operating principles of electronic root canal length measurement devices. Int. Endod. J., 39(8):595-609, 2006.

Pallás Areny, R. Instrumentos Electrónicos Básicos. Barcelona, Marcombo S.A., 2006.pp. 253.

Tay, W. M. \& Braden, M. Dielectric properties of glass jonomer cements-further studies. J. Dent. Res., 63(1):74-5, 1984.

Villat, C.; Tran, X. V.; Pradelle-Plasse, N.; Ponthiaux, P.; Wenger, F.; Grosgogeat, B. \& Colon, P. Impedance methodology: A new way to characterize the setting reaction of dental cements. Dent. Mater., 26(12):1127-32, 2010.
Corresponding author:

Felipe Aguilera Muñoz.

Dental School, Faculty of Medicine

Universidad Austral de Chile

Rudloff 1640

Valdivia

CHILE

E-mail: felipe.aguilera@uach.cl

ORCID: 0000-0002-0390-0018 